\title{
СУДЬБЫ ДАУРСКИХ ОФИЦЕРОВ - УЧАСТНИКОВ АНТИЯПОНСКИХ МЯТЕЖЕЙ В АРМИИ МАНЬЧЖОУ-ГО В АВГУСТЕ 1945 ГОДА*
}

Статья посвящена малоизвестным страницам истории войны СССР с Японией в августе 1945 г. Основу работы составили сведения о вооруженных мятежах в воинских подразделениях Маньчжоу-Го и участии в них офицеров даурской национальности. Изучены дальнейшие биографии отдельных офицеров, их включение в ход граждан-

* Работа выполнена в рамках государственного задания ИМБТ СО РАН по проекту № 0338-2016-0003 «Межкультурное взаимодействие, этнические и социально-политические процессы в Центральной Азии». 
ской войны в Китае, деятельность на различных военных и гражданских должностях после образования КНР.

Ключевые слова: дауры, Маньчжоу-Го, армия, офицеры, военная академия, мятежи, советская армия.

B.D. TSYBENOV L. V. KURAS

\section{THE DESTINIES OF DAURIAN OFFICERS - PARTICIPANTS OF THE ANTI-JAPANESE REBELLIONS IN THE ARMY OF MANCHUKUO IN AUGUST 1945}

The article is devoted the topical pages of the history of the war of the USSR with Japan in August 1945. This paper is based on an analysis of information about armed rebellions in the Manchukuo Army. Officers of the Daurian nationality took part in these rebellions. The author also studied the biographies of some officers.

Keywords: Daurs, Manchukuo, army, officers, military academy, rebellions, the Soviet army.

Свой вклад в победу СССР во Второй мировой войне внесли жители Иркутской области, отправившие на фронт более 200 тыс. чел. Из них домой не вернулись более 100 тыс. солдат. Много иркутян воевало и на заключительном этапе мировой войны, известной как война с Японией. В боях на восточном направлении мужество и героизм проявили иркутская комсомолка М. Цуканова, не сломленная в японском плену [2, с. 39]; рядовой И. Баторов, повторивший подвиг А. Матросова, закрыв собой амбразуру пулемета на подступах к Хайлару. В настоящей работе мы решили кратко осветить малоизвестные в отечественной исторической науке страницы войны СССР с Японией в августе 1945 г. Во всех публикациях неизменно отмечается быстрое победоносное наступление советских войск в Северо-Восточном Китае, захват основных укрепрайонов, сдача в плен солдат и офицеров Квантунской армии. Однако в них не содержится информация о вооруженных антияпонских мятежах в армии Маньчжоу-Го, которые, с одной стороны, способствовали оперативному решению боевых задач советских воинских частей; с другой - явились фактором деморализации японских солдат и офицеров, снижения их боевого духа. Имена организаторов и участников этих мятежей до недавнего времени были известны лишь в узких кругах китайских специалистов и краеведов. Поэтому ныне возникает необходимость в ознакомлении широкой читательской аудитории с событиями минувших лет, восстановлении деталей; имен офицеров даурской национальности, сыгравших немалую роль в отмеченных событиях. Поскольку имеются сведения о судьбе некоторых из них, мы решили включить в работу от- 
дельные данные из их дальнейшей деятельности. Основой для нашей статьи послужили материалы «Истории дауров Китая с древнейших времен до наших дней», изданной в трех частях в 2018 г. под редакцией Мэн Чжидуна; а также ряд публикаций отечественных и зарубежных авторов.

После поражения немецких войск под Сталинградом стало ясно, что рано или поздно Германия и ее союзники рано или поздно будут окончательно разгромлены. В мае 1945 г. немецкие фашисты капитулировали, тем самым оставив Японию одну против объединенной коалиции союзных сил. В этот период даурские чиновники и офицеры, служившие в армии марионеточного государства Маньчжоу-Го, стали более четко осознавать нереальность японских лозунгов «Императорская армия должна победить!», «Завершение священной войны». Восемь офицеров военной академии в Вангийн-сумэ (совр. г. Уланхот аймака Хинган автономного района Внутренняя Монголия) провели тайное собрание, на котором обсудили вопросы антияпонской борьбы. Среди них были Ван Хайшань (даур) и Дугаржав (монгол) [16, с. 434].

8 августа 1945 г. СССР объявил войну Японии, 9 августа председатель ЦК КПК Мао Цзэдун выступил с заявлением «Последняя битва с японскими захватчиками», где отдал приказ 8-й армии и другим формированиям КПК начать контрнаступление. В этом заявлении он также призвал военные и гражданские лица, независимо от национальности, сотрудничать с советскими войсками для общего наступления против японцев. Под мощным натиском объединенных советско-монгольских войск Квантунская армия была вынуждена начать отступление [13]. 10 августа 1945 г. в военной академии в Вангийн-сумэ был издан приказ о переводе курсантов в район Чжэнцзясюаня. Вангийн-сумэ в этот период был одним из узловых центров Маньчжоу-Го. Помимо военной академии, здесь работали два института по подготовке педагогических кадров [10, с. 119]. Согласно приказу все курсанты и офицеры академии должны быть организованы в четыре группы. Во главе этих групп были поставлены японские офицеры. Четвертая группа состояла из курсантов-новобранцев и курсантов второго года обучения. Командование военной академии решило, что группы в своем передвижении должны соблюдать интервал, расстояние между группами должно составлять примерно 10 км. Вечером 10 августа Ван Хайшань и группа офицеров (куда входили монголы и дауры) собралась на экстренное совещание, на котором было принято решение о ликвидации японских офицеров. Солнечным утром 11 августа 1945 г. четыре группы курсантов, ведомые офицерами, прибыли к северной части местности Гэгэн-сумэ. Во время привала офицеры - участники заговора - Э Сюфэн (даур), Бао Чжуанцин и Хао Юнфан застрелили нескольких японских офицеров, включая лейтенанта Йошикаву. После получения известия о начале мятежа, восставшими были убиты японские офицеры в третьей группе, в том 
числе майор Отани. Затем монгольские офицеры и курсанты первой и второй групп перебили своих командиров-японцев. После ликвидации японских офицеров инициативной группой восстания было принято решение о возвращении в Вангийн-сумэ и переходе на сторону народной армии Китая [16, с. 434-435]. Последующие события, имевшие место в августе-сентябре 1945 г. мало изучены нами. Можно предположить, что офицеры и курсанты военной академии ввиду своевременно организованного вооруженного выступления избежали тягот советского плена и органично влились в состав военных подразделений КПК. Следует заметить, что еще в начале 40-х гг. XX в. в частях армии Маньчжоу-Го проводилась антияпонская пропаганда [5, с. 228]. Среди пропагандистов были и дауры. Так, в 1944 г. антияпонские настроения среди солдат и офицеров в Вангийн-сумэ сеял член подпольной организации, цицикарский даур Бу Линь [14, с. 2]. Дауры имелись также среди агентов советской разведки, некоторые являлись разведчиками, выполнявшими особо важные задания [9].

Судьба некоторых организаторов и участников мятежа 11 августа 1945 г., дауров по национальности освещена даурскими учеными. В то же время нам, на данный момент, не удалось найти сведения о Ван Хайшане, являвшемся одним из руководителей мятежа. Известно лишь, что он являлся цицикарским дауром и в 70-х гг. XX в. проживал в г. Хух-хот. Другой уроженец уезда Лунцзян Э Сюфэн (1918-2009) также являлся одним из организаторов вооруженного антияпонского мятежа. Ему было суждено прожить долгую и насыщенную разными событиями жизнь. В 1935-1938 гг. он обучался в военной академии в Вангийн-сумэ (другое название «Хинганская офицерская школа»). В 1936 г., т.е. во время его учебы, японскими властями был казнен один из даурских лидеров Линшен, глава области Северный Хинган Маньчжоу-Го [3, с. 203]. Это событие, очевидно, не могло не оставить свой след в душе будущего офицера. После окончания учебы он остался работать в школе, вероятно, в качестве инструктора. С мая 1940 по май 1945 г. проходил обучение в военном училище в Токио (Япония), после возвращения продолжил работать в военной академии. Как отметили выше, Э Сюфэн был одним из разработчиков операции по устранению японских офицеров. В октябре 1945 г. он был назначен командиром сил самообороны монгольского правительства провинции Нэньцзян. По приказу руководства КПК и региональных органов власти от 20 ноября 1945 г. Э Сюфэн стал командиром вновь созданной монгольской бригады самообороны. «Монгольской» бригада была названа потому, что до 1956 г. дауры не считались отдельной народностью, а продолжали входить в состав монголов [15, с. 93]. Как полагают отдельные специалисты, речь идет о появлении в этот период даурской автономной армии во главе с Э Сюфэном [17, с. 23]. Период был достаточно сложный, Гоминьдан не желал 
сдавать своих позиций, образовав во многих населенных пунктах свои отделения [4, с. 16]. Что касается дальнейшей биографии Э Сюфэна, то он был командиром 5-й кавалерийской бригады Восточно-Монгольской Народной Автономной армии, начальником штаба Хинганского военного округа. Попав в опалу в августе 1947 г., три года провел в тюрьме. После освобождения работал учителем и заместителем директора средней школы в С. Шугуйт. В годы «культурной революции» вновь подвергался преследованиям, в 80-х гг. XX в. он неоднократно обращался в органы власти о пересмотре его дела и впоследствии был реабилитирован. Начиная с 1986 г. Э Сюфэн написал ряд научных и научно-популярных статей об истории и культуре дауров [16, с. 435-436].

Одним из участников событий в местности Гэгэн-сумэ 11 августа 1945 г. был Мэдэлту (1911-1915). Он происходил из даурского рода гобол Восточной Бутхи, китайское имя - Го Донбу. Мэдэлту принял боевое крещение в сентябре 1931 г. в сражении даурских сил самообороны хошуна Морин-Дава с китайскими милитаристами. С 1933 по 1945 г. служил в армии Маньчжоу-Го. Владел русским и японским языками. В августе 1945 г. Мэдэлту выступал в качестве переводчика советских войск, в частности, помог в капитуляции частей армии Маньчжоу-Го, дислоцированных в районе Вангийн-сумэ. Благодаря его деятельности, курсанты и офицеры военной академии были включены в состав 1-й кавалерийской дивизии Восточно-Монгольской Народной Автономной армии. Принимал участие в сражениях с гоминдановскими войсками. В сентябре 1947 г. Мэдэлту был арестован, ему был предъявлен ряд обвинений, включая пособничество Гоминдану, препятствование проведению аграрной реформы, организацию скотоводческих перекочевок во Внутренней Монголии и др. 16 мая 1951 г. Мэдэлту был приговорен к смертной казни. После III пленума ЦК КПК 11-го созыва в декабре 1978 г. дело Мэдэлту было пересмотрено. В июне 1986 г. Комитет общественной безопасности АРВМ, изучив дело Мэдэлту, пришел к выводу об отсутствии состава преступления в его деятельности. Таким образом, было подтверждено, что дело было сфрабриковано. Мэдэлту был реабилитирован, отмечен его вклад в движении за автономию и в Освободительной войне (другое название «Война с Японией») [16, с. 436-437].

Из даурского рода судур происходил Буенбули (1923-2004), еще один участник антияпонского мятежа у Гэгэн-сумэ 11 августа 1945 г. Службу в военной академии в Вангийн-сумэ он начал в 1941 г. После событий 11 августа 1945 г. служил командиром артиллерийской батареи в составе 5-й кавдивизии Восточно-Монгольской Народной Автономной армии. В мае 1947 г. вступил в ряды КПК, в 1947-1948 гг. принимал участие в осаде Чанчуня, сражениях в провинции Ляонин. В дальнейшем Буенбули связал свою жизнь с вооруженными силами, работал инструктором в военном училище. Был награжден многими государственными 
наградами. Долгое время проработал на должности военного комиссара даурского автономного хошуна Морин-Дава [16, с. 437-438]. Национальная автономия дауров была создана в 1958 г. [11]. По всей видимости, даурский автономный хошун Морин-Дава, созданный на территории Бутхи, притягивал к себе многих дауров, желавших работать на благо своей малой родины.

Участником событий 11 августа 1945 г. был даур Су Синбао, уроженец уезда Нэхэ провинции Хэйлунцзян, начавший обучение в военной академии в Вангийн-сумэ в 1938 г. В декабре 1946 г. служил командиром роты в 1-й дивизии Восточно-Монгольской Народной Автономной армии. В июне-июле 1947 г. принимал участие в боях с гоминдановскими войсками. По его приказу был сбит американский истребитель, стоявший на вооружении у Гоминдана. Вскоре Су Синбао был повышен по карьерной лестнице, назначен на должность командира батальона. В 1948 г. он обучался в военно-политической академии Внутренней Монголии, где стал образцовым курсантом. В 1949 г. он стал лучшим среди членов КПК - военнослужащих Внутренней Монголии, в 1950 г. был награжден как лучший военнослужащий Внутренней Монголии. В 1959 г. Су Синбао принимал участие в юбилейных мероприятиях, посвященных 10-й годовщине основания КНР [16, с. 438-439].

Накануне войны СССР с Японией инструктором в военную академию в Вангийн-сумэ был назначен Э Вэньлян, цицикарский даур. В августе 1945 г. он принял активное участие в антияпонском мятеже. Известен тем, что в 1946 г. вместе с Ван Хайшаном арестовал и казнил агента Гоминдана. В то же время другой офицер, Го Баошань поверив подосланным агентам, вместе со 100 офицерами и солдатами, бежали в Тунляо, к гоминдановским силам. Э Вэньлян, будучи начальником штаба 2-й кавалерийской дивизии Восточно-Монгольской Народной Автономной армии, предпринял попытку перехватить изменников. В 1947 г. его дивизия вошла в состав четвертой армии Китайской народно-освободительной армии и участвовала во многих сражениях с силами Гоминдана. В 1949 г. Э Вэньлян поступил в военную академию в г. Цицикар. После окончания учебы из-за семейных проблем был вынужден уйти из армии. Работал в налоговой службе Шилингольского аймака АРВМ. Пострадал во время «культурной революции», был объявлен контрреволюционером [16, с. 439]. «Культурная революция» стала серьезным испытанием для многих людей, прошедших к тому времени период Маньчжоу-Го, Освободительную и гражданскую войны. Даурские национальные кадры, как и кадры других национальных меньшинств, подверглись серьезным гонениям [12].

Возвращаясь к теме антияпонских мятежей в августе 1945 г., отметим, что мятеж в районе Гэгэн-сумэ не был единственным. Другим вооруженным мятежом солдат и офицеров армии Маньчжоу-Го, в кото- 
ром приняли участие дауры, было антияпонское выступление в районе р. Шэнэхэн 11 августа 1945 г. Заметим, что Шэнэхэн находится в аймаке Хулунбуир, а вышеотмеченные Вангийн-сумэ и Гэгэн-сумэ в аймаке Хинган. Поэтому трудно сказать, были ли связаны между собой эти вооруженные выступления. Предыстория мятежа у р. Шэнэхэн такова: 9 августа 1945 г. в 9 часов утра командующий войсками Квантунской армии в районе Хайлара генерал-лейтенант Номура отдал приказ командующему 10-м военным округом армии Маньчжоу-Го генерал-лейтенанту Го Вэньлину (даур по национальности) отступить в сторону хребта Большой Хинган. В 17 часов вечера того же дня Го Вэньлин и начальник штаба Чжэнчжуржаб (монгол) прибыли в п. Нантунь. Сюда же прибыли два кавалерийских полка: 50-й и 51-й. 10 августа 1945 г. в два часа ночи более 500 солдат под командованием Го Вэньлина и Чжэнчжуржаба выступили из Нантуня в юго-восточном направлении. Во время марша вышеуказанные военачальники пришли к выводу о необходимости радикальных мер виду быстро меняющейся обстановки. Было решено убить всех японских офицеров, следующих с ними; и сдаться в плен советским войскам. Время выступления было назначено на утро 11 августа. Го Вэньлин попросил Чжэнчжуржаба проинформировать об этом решении надежных офицеров из числа монголов (включая дауров). Прибыв к р. Шэнэхэн полки расположились на привал, что вызвало недовольство японских офицеров. В частности, командир артиллерийской батареи, майор Осима (японец), выхватив саблю, требовал ускорения темпов движения. В ночь с 10 на 11 августа офицеры - участники вооруженного мятежа вновь обсудили на тайном совещании детали выступления. В итоге было принято решение о продолжении движения на восток утром 11 августа, чтобы усыпить бдительность японцев. После трех сигнальных выстрелов приступить к их ликвидации. Утром 11 августа 1945 г. во время марша восточнее местности Шэнэхэн-сумэ прозвучали три выстрела. В течение 10 минут все японцы, численностью более 20 чел., были перебиты. Затем Го Вэньлин распорядился отправить парламентера, бурята Жамсарана (в свое время являвшегося учителем русского языка) с предложением о сдаче в плен. После переговоров, 12 августа 1945 г. в 5 часов утра в местности Улан-Харгана советская армия разоружила солдат Го Вэньлина [16, с. 440]. По данным информаторов, место, где солдаты бросали японские шапки и оставили лошадей, ныне называется «Малгай гарта» [8]. После сдачи в плен Го Вэньлин дал подробные показания командованию советской армии 14 августа 1945 г. Известно, что в годы «культурной революции» он был осужден, погиб в 1969 г. О дальнейшей судьбе Чжэнчжуржаба у нас нет данных, что побуждает к дальнейшему поиску сведений о нем в китайских источниках. В целом, изучаемая проблема антияпонских мятежей в армии Маньчжоу-Го в августе 1945 г. требует пристального внимания. Неосвещенными 
остаются вооруженные выступления под командованием генерал-майора Го Вэньтуна (даур) и других офицеров армии Маньчжоу-Го. Известно, что Го Вэньтун был связан с подпольной антияпонской организацией в Хайларе и передавал ей секретные сведения о Квантунской армии [7, с. 161; 6]. Связи дауров, подпольщиков с советской разведкой имеют давнюю историю. Восходит она к деятельности даурских лидеров Мэрсэ и Фуминтая, бурята Ц-Е. Цыдыпова в Хулунбуире в 20-х гг. XX в. [1].

Проблема антияпонских вооруженных мятежей в армии Маньчжоу-Го, затронутая нами в настоящей статье, носит большей частью постановочный характер. Многие события и детали вышеотмеченных вооруженных выступлений остаются неисследованными, равно как и степень участия в них офицеров даурской национальности. Тем не менее, нам удалось установить имена дауров, имевших высокие военные чины в армии Маньчжоу-Го; и их прямую причастность к событиям 11 августа 1945 г.

\section{Список использованной литературы и источников}

1. Базаров Б. В. Неизвестное из истории панмонголизма / Б. В. Базаров. Улан-Удэ : Изд-во БНЦ СО РАН, 2002. - 67 с.

2. Васильева А. Иркутяне на фронтах Великой Отечественной / А. Васильева, В. Титова // Иркутская область в 1941-1945 гг:: единство фрронта и тыла. Иркутск : Изд-во БГУЭП, 2010. - С. 37-39.

3. Государственная и квазигосударственная природа Маньчжоу-Го: исторические очерки / П. Н. Дудин, В. В. Досовицкая, Л. В. Курас, С. В. Карасев, А. В. Тубчинов, В. М. Фоменко, Б. Д. Цыбенов, А. В. Шемелин ; науч. ред. Б. В. Базаров. Иркутск : Изд-во «Оттиск», 2016. - 254 с.

4. Ларин В. Л. История Северо-Восточного Китая XVII-XX вв. Кн. 3 : Северо-Восточный Китай в 1945-1978 гг. / В. Л. Ларин, Г. П. Белоглазов. - Владивосток : Дальнаука, 2004. - 344 с.

5. История Северо-Восточного Китая XVII-XX вв. Кн. 2 : Северо-Восточный Китай. 1917-1949 гг. / А. И. Крушанов (гл. ред.), Е. Ф. Ковалев, М. С. Капица, М. Л. Титаренко, Г. С. Каретина, Г. Ф. Захарова. - Владивосток : Дальневост. кн. изд-во, 1989. - 350 с.

6. Курас Л. В. Антияпонская освободительная борьба дауров и баргутов в годы Второй мировой войны / Л. В. Курас, Б. Д. Цыбенов // Иркутский историко-экономический ежегодник: 2016. - Иркутск : Изд-во БГУ, 2016. - С. 411-419.

7. Курас Л. В. Новые данные о разведывательной деятельности Японии и СССР в Монголии и Хулунбуире в годы Второй мировой войны / Л. В. Курас, Б. Д. Цыбенов // Власть. - 2016. - № 11. - С. 158-163.

8. Полевые материалы Цыбенова Б.Д., собранные в ходе научной командировки в Хулун-Буирский аймак Автономного района Внутренняя Монголия КНР в октябре 2018 г.

9. Ширабон Р. Разведчики - «панмонголисты» / Р. Ширабон, Б. Раднаев // Информ-полис. - 2012. - 4 июля. - С. 30.

10. Цыбенов Б. Д. Культура и образование дауров в первой половине XX в. I Б. Д. Цыбенов // Известия Иркутского государственного университета. Серия История. - 2018. - Т. 25. - С. 115-122. 
11. Цыбенов Б. Д. История создания даурского автономного хошуна Морин-Дава (1945-1958 гг.) / Б. Д. Цыбенов, Юй Шан // Известия Иркутского государственного университета. Серия История. - 2017. - Т. 22. - С. 113-123.

12. Цыбенов Б. Д. Социально-политическое развитие даурского автономного хошуна Морин-Дава в 1958-1984 гг. / Б. Д. Цыбенов // Власть. — 2018. — № 7. C. 205-210.

13. Dayur ündüsüten-ü tobči teüke = Краткая история даурского народ / naiyrayulan bičikü duyuyilang naiyrayulaba; Meng Ji Düng, Üljeyitü, Bayar. Kükeqota : Öbür Mongyol-un arad-un keblel-ün qoriy-a, 1989. - 300 c. (На старомонгольской письменности)

14. Duo Zhansheng. Meilisi dawoerzu renwulu = Биографии даурских деятелей района Мэйлисы / Zhansheng Duo. - Haerbin : Heilongjiang renmin chubanshe, 2017. - 267 с. (На кит. яз.)

15. Manduertu. Dawoerzu baike cidian = Энциклопедия даурского народа / Manduertu. - Hulunbeier : Neimenggu wenhua chubanshe, 2007. - 731 c. (На кит. яз.)

16. Meng Zhidong. Zhongguo dawoerzu tongshi: quan 3 се = История дауров Китая с древнейших времен до наших дней. В трех частях / Zhidong Meng. Shenyang : Liaoning minzu chubanshe, 2018. - Ч. II. - 687 с. (На кит. яз.)

17. Wu Weirong. Meilisi dawoerzu qu wenshi ziliao. Di-yi ji. = История и культура даурского национального района Мэйлисы. Часть 1 / Weirong Wu. — Qiqihaer shi, 1989. - 214 с. (На кит. яз.)

\section{Информация об авторах}

Цыбенов Базар Догсонович - кандидат исторических наук, старший научный сотрудник, Институт монголоведения, буддологии и тибетологии СО РАН, 670047, г. Улан-Удэ, ул. Сахьяновой, 6; e-mail: bazar75@mail.ru

Курас Леонид Владимирович - доктор исторических наук, профессор, главный научный сотрудник, Институт монголоведения, буддологии и тибетологии СО РАН, 670047, г. Улан-Удэ, ул. Сахьяновой, 6; e-mail: kuraslv@yandex.ru

\section{Authors}

Bazar D. Tcybenov - PhD in History, Research Fellow, Institute for Mongolian, Buddhist and Tibetan Studies, the Siberian Branch of the Russian Academy of Sciences, 6 Sakhyanova St., 670047, Ulan-Ude, Russia; e-mail: bazar75@mail.ru

Leonid V. Kuras - Doctor of History, Professor, Senior Research Associate, Institute for Mongolian, Buddhist and Tibetan Studies, the Siberian Branch of the Russian Academy of Sciences, 6 Sakhyanova St., 670047, Ulan-Ude, Russia; e-mail: kuraslv@yandex.ru 